\title{
Generating Renewable Energy from Municipal Waste Sector: A Comparative Study between Japan and Indonesia
}

\author{
Jatmiko Wahyudi and Mayang Rahmi Novitasari
}

\begin{abstract}
Although Indonesia has abundant resources to produce renewable energy (RE) from municipal solid waste (MSW), the implementation of waste to energy (WtE) concept remains low due to several factors. Approximately, 200,000 tons of MSW per day are generated in Indonesia. Improper waste management system in Indonesia is not only causing environmental problems but also inhibiting to get benefits from RE production. This study which was funded by Japan International Cooperation Agency (JICA) was conducted to obtain a comparative description of WtE implementation between Japan and Indonesia as well as to formulate possible strategies for improving WtE implementation in Indonesia. Direct observations and a series of qualitative depth interviews with stakeholders were conducted both in Japan and Indonesia. This study revealed that the two countries have a different approach of WtE implementation. The implementation of WtE in Japan mostly relies on thermal treatment as a form of intermediate treatment of MSW to reduce the amount of waste sent to landfill as well as to increase the life span of landfill. In Indonesia, WtE implementation mostly uses the biological treatment (anaerobic digestion) as a part of final treatment of MSW in landfill. Conducting integrated waste and energy management system is one of best practices from Japan that can be learned and applied in Indonesia to improve the implementation of $\mathrm{WtE}$.
\end{abstract}

Index Terms - Incineration, landfill gas, municipal solid waste, waste to energy.

\section{INTRODUCTION}

Indonesia, a home to more than 260 million people, faces serious problem in managing municipal solid waste (MSW). As a result of economic development and population growth, the amount of MSW generation in Indonesia continued to increase causing serious problems towards the environment as well as public health over years. In Indonesia, it is predicted 38.5 million tons of MSW generated per year with $2-3 \%$ annual growth rate [1]. In addition, the diversity of MSW becomes another problem since plastics and synthetic materials became widely used and were disposed in large amounts.

Waste to Energy (WtE) becomes one of promising methods to tackle waste problem by converting waste into renewable energy in the form of electricity and heat. Actually,

Manuscript received May 7, 2018; revised November 13, 2018. This study which was funded by Japan International Cooperation Agency (JICA) was a part of Staff Enhancement Program conducted by National Development Planning Agency (BAPPENAS) Indonesia

Jatmiko Wahyudi is with Regional Development Planning Agency, Pati, 59113, Indonesia (Corresponding Author; e-mail: jatmiko_tkuns@yahoo.com).

Mayang Rahmi Novitasari is with National Development Planning Agency, Jakarta, 10310Indonesia (e-mail: mayang.sari@bappenas.go.id). the application of $\mathrm{WtE}$ concept is already practiced by ancient people by burning biomass to produce energy for cooking and illuminating. There are several treatment options of WtE worldwide such as anaerobic digestion (AD), incineration and gasification [2], [3]. The volume and characteristic of MSW as the feedstock are crucial factors to determine the choice of WtE technology. For instance, MSW with high organic and moisture contents is more suitable for biological treatment (AD) than thermal treatment like incineration and gasification [4].

Similar to Indonesia, many cities in Japan also encounters waste problems due to the increase of MSW generation and land shortage for landfills. Even though the amount of waste has been decreasing in recent years, total waste emission in Japan was still high reaching 44 million tons by 2015 [5]. Incineration becomes a primary method to dispose waste quickly as well as to generate renewable energy across the country. Total power generation capacity of incinerators in Japan reaches 1,934 Mega Watt (MW) that is far better compared to Indonesia [5]. It is interesting to investigate the reason why the result of WtE implementation in Japan is higher than that of in Indonesia. This study aims to obtain a comparative description of WtE implementation between Japan and Indonesia as well as to formulate possible strategies for improving WtE implementation in Indonesia.

\section{MATERIAL AND MethoD}

This study was a part of Staff Enhancement Program conducted by National Development Planning Agency (BAPPENAS) Indonesia. During the program, the authors visited Japan from 2 to 27 October 2017 to study the implementation of WtE in Japan particularly in Tokyo and Yokohama as sampling of cities in Japan. Primary data were collected by conducting direct observation in 2 incinerators that are Minato incineration plant in Tokyo and Tsuzuki incineration plant in Yokohama. In addition, interviews were conducted with an official from Tokyo Metropolitan Government and Yokohama City Government, employees from the incinerators, researchers from National Institute for Environmental Studies, Tsukuba Japan and Environmental Research Institute Inc Tokyo. Secondary data were obtained by reviewing literatures and documents related to $\mathrm{WtE}$ concept in Japan and Indonesia.

\section{RESUlT AND DisCUSSION}

\section{A. Current Situation in Indonesia}

About $361 \mathrm{MW}$ of electricity is potentially resulted by 
processing 8,733 tons/day of waste in Jakarta. Waste processing of 682 tons/day in Surabaya potentially generates $106 \mathrm{MW}$ of electricity [6]. From the example of the two big cities, it can be seen that waste has the potential to produce renewable energy and to reduce the dependency on fossil fuels. Unfortunately, the contribution of $\mathrm{WtE}$ in the final energy mix in Indonesia has remained low compared to its potential. The Government of Indonesia (GoI) has begun to encourage the development of $\mathrm{WtE}$ (especially for municipal waste treatment) since 2011. In 2016, The GoI revised target regarding the share of new and renewable energy (NRE) in the final energy mix from $23 \%$ by 2025 to $23 \%$ by 2020 and $31 \%$ by 2030 [7], [8].

Since the implementation of decentralization policy in 2004, local government in Indonesia becomes a key player in implementing policies in many public sectors including waste and energy. According to Waste Management Law $18 / 2008$, except Jakarta as capital city of Indonesia, local government (municipality/regency) has responsibility in managing MSW and most local government use landfill as a final disposal site [9]. Biological treatment in the landfill becomes preferred option because it needs low investment and the majority of MSW generated is decomposable organic waste.

Some local governments show a good response in utilizing landfill gas (LFG) for cooking and generating electricity. For instance, the government of Pati, Malang and Kendari utilize LFG for cooking to households surround the landfill. While in Jakarta, using advanced technology enables the local government to produce 8-9 MW electricity from LFG. Until 2016 , Indonesia has already built $17,6 \mathrm{MW}$ on-grid WtE plant by sanitary landfill technology. Indonesia also has 11,6 MW for biogas power plant until 2016 [10].

The GOI has issued the Presidential Decree 18 of 2016 as a legal system to support the construction of waste-based power plant (PLTSa) using thermal technology in 7 big cities in Indonesia. Unfortunately, the regulation should be annulled by the judiciary due to the adverse impact of the technology and the opposition by public. The GOI has a strong willingness to construct PLTSa and even, the GOI has a plan to increase the number of cities as locations of PLTSa from 7 big cities to 10 big cities. New regulation is prepared as well as the selection of $\mathrm{WtE}$ technologies are assessed to minimize the negative impacts of $\mathrm{WtE}$ plants operation in particular the hazardous emissions.

Several challenges to establish PLTSa in Indonesia consist of some issues including the land availability, waste management system, economic feasibility, local government support, technology, and social economic issue. Waste management system determines the success and sustainability of $\mathrm{WtE}$ in Indonesia. Some $\mathrm{WtE}$ pilots project that has been built in Indonesia not working because of instability of waste supply to be processed into energy. In addition, the diversity of waste and improper sorting waste from upstream to downstream become barriers to optimize $\mathrm{WtE}$ working process.

The optimization of AD technology performance depends on the ability of local government to reduce the amount of inorganic waste sent to landfill site. Therefore, it is important to increase community awareness to separate waste properly.
The waste pickers (scavengers), an active group in collecting recyclable waste, play an important role to reduce the amount of inorganic waste in landfill site because most of recyclable materials collected by scavengers are inorganic wastes such as plastic, rubber and metal [11].

Lack of coordination and cooperation among stakeholders becomes another problem for developing $\mathrm{WtE}$ in Indonesia since many government and non government institutions involve and play in different roles in the waste and energy sectors [12]. Waste Management Law 18/2008 and Energy Law 30/2007 state that local government has responsibilities in managing both waste and energy. However, $\mathrm{WtE}$ is a high cost project and without financial support from national government and other institutions, the investment of $\mathrm{WtE}$ project is unaffordable for local government.

Another option for funding WtE projects is Public Private Partnership (PPP) scheme. However, not many private sectors engaged in the effort to process waste into energy. Lower selling price of electricity generated to PLN (Indonesia Electric Company) and no incentive mechanism inhibit private sector to be involved in $\mathrm{WtE}$ projects. In order to make the $\mathrm{WtE}$ projects in Indonesia commercially sustainable and market oriented, it is crucial for the government to encourage and to attract the private sector in promoting $\mathrm{WtE}$ by providing facilities like tax and custom exemption.

\section{B. WtE Implementation in Japan}

Japan uses waste to energy as one form of intermediate treatment on waste generated before disposed to landfill Incinerator technology becomes main waste treatment method because of the difficulty for providing land for landfills in most cities in Japan. The primary advantage of operating incinerator is its capability in reducing weight and volume of waste until $75 \%$ and $90 \%$, respectively [3]. Even, the latest Japanese incineration technology can reduce the volume of solid waste up to $97.5 \%$. The majority of MSW generation in big cities like Tokyo is combustible waste therefore reducing weight and volume of MSW through incineration process can reduce the amount of MSW disposed of by landfill significantly [Fig 1]. As a secondary advantage is the capability of incinerator to generate electricity and heat. There are 1141 incinerators operated in Japan by 2015 with total capacity 181,891 tons/day (Table 1). National average of incineration rate is over $75 \%$ placing Japan as a leading country worldwide in the number of incinerator as well as the incineration rate [Fig 2].

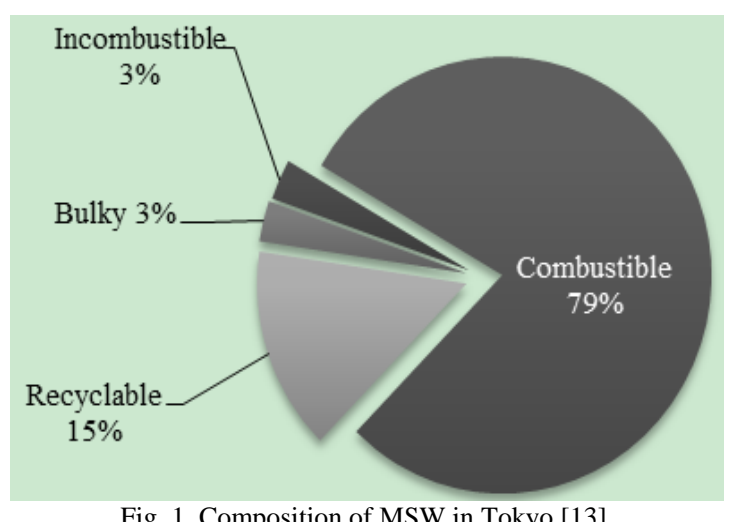

Fig. 1. Composition of MSW in Tokyo [13]. 
TABLE I: THEPERFORMANCE OF INCINERATORS IN JAPAN IN FISCAL YEAR $2015[5],[14]$

\begin{tabular}{lll}
\hline \hline Parameters & Value & Unit \\
\hline Number of plants & 1,141 & Plant \\
Total Capacity & 181,891 & tons/day \\
Capacity per plant (average) & 159 & tons/day \\
Number of plants using residual heat & 765 & Plant \\
Number of plants with power generation facilities & 348 & Plant \\
Total power generating capacity & $1,934,000$ & kilowatts \\
Power generation efficiency & 12.59 & $\%$ \\
\hline \hline
\end{tabular}

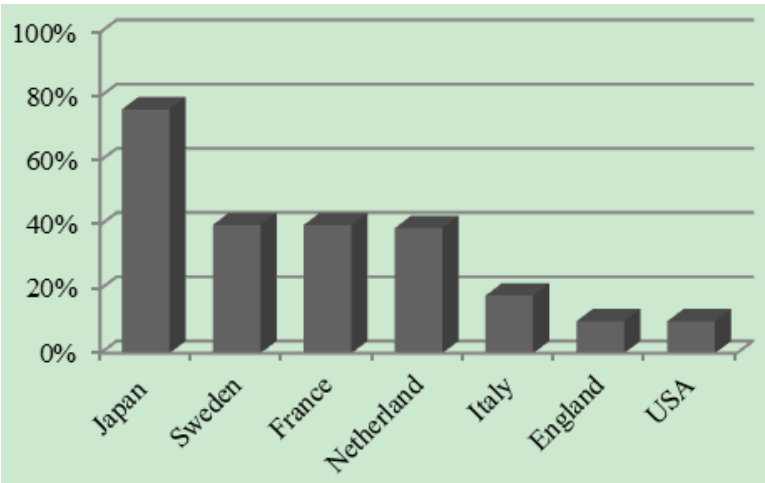

Fig. 2. Comparison of incineration rate in several countries [14].

Tokyo, one of prefectures in Japan, consists of 23 wards/cities relying on 21 incinerators across Tokyo to tackle its MSW problem. In 2000, the responsibility in managing MSW was shifted from Tokyo Metropolitan Government (TMG) to the government of 23 wards. The Clean Authority of Tokyo is a special purpose municipal body established by the consensus of 23 Cities, based on the Local Autonomy Act, in order to deal with this joint waste management including the management of all incinerators. All incinerators produce electricity but only five of them are designed also for producing heat. By 2016, in total, 660 million KWh electricity was sold from all incineration plants in Tokyo and US\$ 117,66 million was generated as revenue from selling electricity. In addition, US\$ 1,92 million was revenue generated from selling $501.000 \mathrm{GJ}$ of heat. About $60 \%$ of total generated power is used within facilities to operate incinerator and the rest is sold to power companies and heat supplying companies. Two incineration plants namely Shin-koto and Itabashi incineration plants distribute heat directly to households, schools, heated pools, tropical museums, and other facilities around incineration plant [15].

All incinerators in Japan have also used high combustion temperatures $\left(800-1000^{\circ}\right.$ Celsius) to prevent the production of dioxins. Dioxin becomes a major health and environmental issue since it was detected contained in fly ash from incinerator in Japan in 1983. Due to the many additional equipment for treating the exhaust residues, the cost for construction and operation increase. The investment needed for an incineration plant is about US\$ 448 Million. Some incinerators in Tokyo were built by the local government (Tokyo Metropolitan Government) with National Government's subsidy and the rest are funded by private sector. The operational and maintenance budgets are funded by income from selling electricity and heat. The selling price (Feed in Tariff/Fit) of electricity generated by incinerator is fluctuated. Feed in Tariff (FiT) for electricity from renewable energy sources including waste to energy is regulated by the
Electric Utilities Act. Ministry of Economy, Trade and Industry (METI) defines the purchase price and purchase period for each category of renewable energy at the beginning of every fiscal year.

Related to licensing, the incinerator to be built or renovated shall be in accordance with the standards established by the Government of Japan through its regulation, especially a strict standards for prevent pollution. Periodically, environmental measurements around the incinerator are also informed through the Tokyo Clean Authority website. The exhaust gas measurements are also informed directly and real time through an information boards. In addition to the standard, the most important licensing is the approval of local residents and environmental permits. Communications with the community are carried out thoroughly, such as: a) providing explanations to the community when establishing and renovating, negotiations are made several times, until community approval is obtained; b) at the time of execution, continuous follow-up do to eliminate public anxiety; and c) conducting a public tour study at an incinerator facility. Protection for neighborhood is also done when building and renovating facilities, such as: a) give attention to the design of the building to harmonize with the surrounding area; b) restrict the factory's exit and entry times, use of tools, and so on to reduce noise and vibration. Protection for neighborhood is also done while the work process every day, such as: a) prevention of noise, vibration, and odor; b) design of garbage collector route, congestion prevention, and so on.

In order to improve the energy self-sufficient rate, Japanese government encourages private companies to develop biomass power generation. Some private companies operate biomass power generation by methane fermentation. BIOENERGY Corporation, the largest methane fermentation plant in Japan, produced $24,000 \mathrm{kWh}$ of power generated per day from food waste. The total amount of food waste generated in 2013 is more than 19 million tons in which $83 \%$ of total food waste was contributed by food manufacturing industries [16]. Two determinant factors to ensure the sustainability of biomass power generation plant in Japan are the certainty of food waste supply as feedstock and financial incentive to reduce production cost. Even though about half of total energy generation from BIOENERGY Corporation is sold to Power Company, the most income comes from food waste producer like food industries and restaurants. Under extended producer responsibility (EPR) policy, producers have obligations to contribute physically as well as financially to minimize the impact of post-consumer wastes

\section{Possible Implementation Strategy of WtE in Indonesia}

Most of WtE (PLTSa) in Indonesia are using sanitary landfill technology. In small cities and rural areas, this approach can be used, but for a big city that has very limited land while the waste generation is very high, another approach is needed. One possible approach to be applied in big cities in Indonesia is a PLTSa with incineration technology combined with $3 \mathrm{R}$ (reduce, reuse and recycle) programs.

Several factors have to be considered in applying waste to energy in Indonesia: 


\section{1) Planning and administration aspects}

Providing data is still a challenge in Indonesia. For example, in order to construct an incinerator, the detail and accurate data like the amount of combustible waste generated and caloric value of MSW are needed to ensure the continuity of feedstock and to determine the capacity of the plant. However, according to the regulation in Indonesia, waste is not sorted into combustible and incombustible wastes like in Japan. In Indonesia, waste is sorted into five categories that are 1) waste contain toxic and hazardous materials; 2) decomposable waste (organic); 3) reusable waste; 4) recycled waste; and 5) other wastes. Consequently, there is no data about combustible waste because the municipalities only have data regarding the com $\mathrm{v}$ position and the amount of the five types of wastes. The government has built some $\mathrm{WtE}$ installations as pilot projects but have not succeeded and not give better impact due to lack of comprehensive grand planning. Regulations in waste and energy sectors in all levels (national, provincial and local) has to be improved and designed to support the implementation of $\mathrm{WtE}$. One of lesson learned from Japan is that the country was intensively updating their regulation by revising some articles to fulfill with current situation and to answer also the issues occurred. This can happen through an accurate data, and a solid well functionally collaboration among stakeholders.

\section{2) Technological aspect}

Majority municipalities in Indonesia do not confronted with land scarcity issue, except some big cities like Jakarta and Surabaya, therefore land filling is a preferred option for disposing waste. One of challenges in implementing $\mathrm{WtE}$ in the landfill is that most of landfill in Indonesia still uses an open dumping system (Fig 3). The production of LFG in open dumping landfill is lower compared to controlled and sanitary landfills. On the one hand, technology installed in controlled/sanitary landfill can maximize to capture LFG. On the other hand, the instalment of technology causes the increase of investment. The decision to select type of landfill technology has to correspond to characteristic of city and the capacity of local authority in managing the technology. The characteristic of thermal technology (incineration) that can eliminate MSW quickly places the technology as the best option to tackle waste problem in big cities. To deal with public opposition regarding incineration, the government has to select a secure and proven incineration technology. PLTSa must have complete specifications in handling flue gas, and supported by provision of secure landfill to handle ash (final residue) produced.

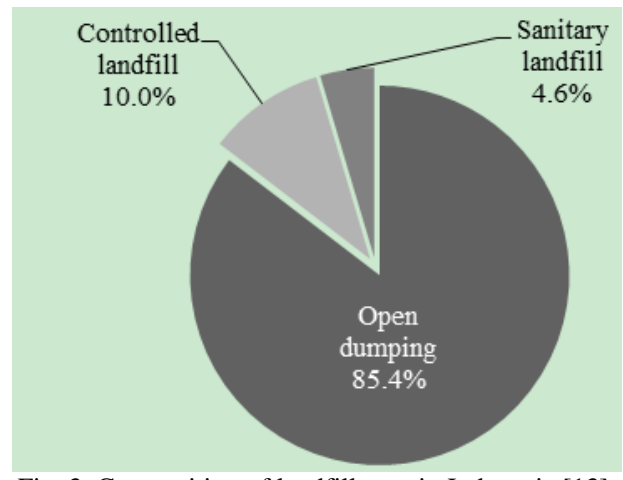

Fig. 3. Composition of landfill type in Indonesia [13].

\section{3) Management aspect}

WtE implementation can only run optimally if the upstream waste management, especially sorting and collection has also been running well. This is closely related to the type of waste that will be processed by $\mathrm{WtE}$ installation. To achieve integrated waste management from upstream to downstream, a clearer organization of managers both vertically (national-local government) and horizontally (government-private-enterprise) is required. The capabilities of local authorities in managing $\mathrm{WtE}$ project determine the sustainability of WtE operation.

\section{4) Funding aspect}

The application of $\mathrm{WtE}$ technology requires a high budget allocation. Solo, one of big cities in Indonesia, requires approximately US\$ 30 million of investment and US\$ 3 million/year of tipping fee to construct and to operate incinerator for treating 265 tons/day of MSW [17]. It is difficult for the municipal government of Solo to allocate funding for the investment and tipping fee. Although WtE in landfill need less investment than incinerator, it is still unaffordable for local government. The construction of sanitary landfill in Pati regency, a small city in Central Java Province, in 2018 requires US\$ 1 million. Hence, the government of Pati regency still operates 2 open dumping landfills even though according to Law 18/2008, open dumping landfills have to be closed maximum in 2013. Budget constraint and financial support from national government and parallel with scheme PPP can be one of solutions to overcome funding problems. The financing scheme needs to be made in a comprehensive scheme, not fragmented between one processes to another.

\section{CONCLUSION}

Undeniable, Japan shows far better achievement in WtE implementation compared to Indonesia. The succeed of $\mathrm{WtE}$ implementation is not only depending on waste management system but also depending on the policy in managing energy sector. In waste sector, the Japanese government ensures the quality and the sustainability of feedstock supply like incombustible waste and food waste. Good sorting process prevents the amount of unwanted materials sent to $\mathrm{WtE}$ plants. EPR scheme is implemented well enabling WtE companies to get sufficient funding to run their operation.

Actually sorting process and EPR scheme for wastes has been regulated in Indonesian Waste Management Law however the implementation are still limited. Generating RE from landfill is still the best option for $\mathrm{WtE}$ project since most of MSW in Indonesia is treated in landfill. Two challenges regarding LFG generation are the majority of landfill applying open dumping system and the low number of controlled and sanitary landfill producing LFG. Financial and technical supports from national government are needed to strengthen the capacity of local governments in managing landfills. Continuous education and campaign is important to increase public awareness regarding sorting process to prevent inorganic waste sent to landfill. Furthermore low tipping fee in waste sector and lack of incentives inhibits private companies to invest in $\mathrm{WtE}$ plant using thermal 
treatment.

\section{ACKNOWLEDGMENT}

The authors gratefully acknowledge the funding support for this study provided by Japan International Cooperation Agency (JICA) under the scheme of Staff Enhancement Program conducted by National Development Planning Agency (BAPPENAS) Indonesia.

\section{REFERENCES}

[1] D. R. Wijayanti and S. Suryani, "Waste bank as community-based environmental governance: a lesson learned from Surabaya," Procedia - Social and Behavioral Sciences, vol. 184, pp. 171-179, 2015.

[2] Y. Dhokhikah, Y. Trihadiningrum, and S. Sunaryo, "Community participation in household solid waste reduction in Surabaya, Indonesia," Resources, Conservation and Recycling, vol. 102. pp 153-162, 2015.

[3] P. Albores, K. Petridis, and P. K. Dey, “Analysing efficiency of waste to energy systems: using data envelopment analysis in municipal solid waste management," Procedia Environmental Sciences, vol. 35, pp. 265-278, 2016

[4] C. Meidiana and T. Gamse, "Development of waste management practices in Indonesia," European Journal of Scientific Research, vol. 40, pp. 199-210, 2010

[5] Japan Ministry of Environment,"Municipal solid waste emissions and disposal in FY2015," Tokyo: PERS release, 2016.

[6] Indonesian Ministry of Energy and Mineral Resources (MEMR), "Perkembangan Percepatan Pembangunan Pembangkit Listrik Berbasis Sampah,” Jakarta, 2016.

[7] The Government of Indonesia (GOI), Government Regulation No. 79/2014 Government of Indonesia, Jakarta, 2014.

[8] The Government of Indonesia, "President Decree Regarding National Energy General Plan, 2016-2050," Government of Indonesia, Jakarta, 2016.

[9] H. Sudibyo, A. I. Majid, Y. S. Pradana, W. Budhijanto, Deendarlianto, and A. Budiman, "Technological evaluation of municipal solid waste management system in Indonesia," Energy Procedia, vol. 105. pp. 263-269, 2017.
[10] Indonesian Ministry of Energy and Mineral Resources (MEMR), "Data Eksisting PLTSa dan PLTBg di Indonesia Tahun 2016,” Jakarta, 2017.

[11] S. Sasaki, T. Araki, A. H. Tambunan, and H. Prasadja, "Household income, living and working conditions of dumpsite wastepickers in Bantar Gebang: Toward integrated waste management in Indonesia,' Resources, Conservation and Recycling, vol. 89, pp. 11-21, 2014.

[12] J. Wahyudi, T. B. A. Kurnani, J. Clancy, "Biogas Production in Dairy Farming in Indonesia: Challenge for Sustainability," International Journal of Renewable Energy Development, vol. 4, pp. 219-226, 2015.

[13] Bureau of Environment Tokyo Metropolitan Government, "3Rs and waste management in Tokyo," Tokyo, 2015.

[14] K. Ikeda, "Current state and problems of Japanese excessive "incineration-ism," Tokyo: Environmental Research Institute Inc., 2017.

[15] Clean Authority of Tokyo, "Waste report 2017: Towards A recycling-oriented society," Tokyo, 2017.

[16] Japan Organics Recycling Association (JORA), "Food waste utilization in Japan," Tokyo, 2017.

[17] Indonesian Ministry of Energy and Mineral Resources (MEMR), “Sampah Menjadi Energi Buku Panduan,” Jakarta, 2015.

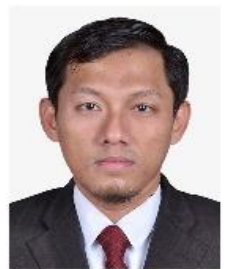

Jatmiko Wahyudi graduated from Chemical Engineering Department, Universitas Sebelas Maret, Indonesia, and got the master degrees in environmental and energy management from the University of Twente, the Netherlands. His major fields of research are the waste management, greenhouse gas and waste to energy. He works for Regional Development Planning Agency, Pati, Central Java Province,

Indonesia as a researcher.

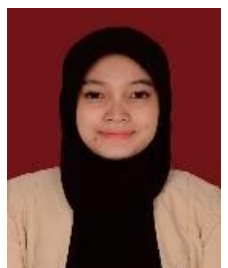

Mayang Rahmi Novitasari graduated from Gadjah Mada University, Indonesia and got the master degrees in urban and regional planning from same university. Her major fields of research are the renewable energy development, green economy, and urban planning. She is a planner in National Development Planning Agency, Jakarta, Indonesia. 